\title{
IMPLEMENTATION OF THINK TALK WRITE (TTW) MODEL TO IMPROVE POETRY WRITING SKILL ON FOUR GRADE STUDENT
}

\author{
Febi Sulistyo Rini, Muhammad Ismail Sriyanto, Idam Ragil Widianto Atmojo \\ Universitas Sebelas Maret \\ akufebisulis@gmail.com
}

\section{Article History}

accepted 09/07/2018

approved 01/08/2018

published 17/09/2018

\section{Keywords}

think talk write model, poetry writing skill

\begin{abstract}
Lowness of poetry writing skill on four grade student of jetis 2 primary school makes researcher done a research with Think Talk Write model of study. The purpose of this research was to improve poetry writing skill on student. The type of this research was Classroom Action Research because to emphasize improvements in classroom learning. Result of this research was average score of students' poetry writing on first test before the action done was 47. After cycle one, the score increased to 71,83, and at cycle 2 it became 77,67. The previous classical comprehensiveness of poem writing skill was $20 \%$, then increased to $60 \%$ on first cycle, and rose again into $77,67 \%$ on second cycle. The conclusion of this research was the implementation of Think Talk Write (TTW) model can improve students' skill on writing poetry on four grade students of Jetis 2 Primary School in academic year of 2017/2018.
\end{abstract}

Social, Humanities, and Education Studies (SHEs): Conference Series https://jurnal.uns.ac.id/shes

p-ISSN 2620-9284

e-ISSN 2620-9292 


\section{PENDAHULUAN}

Pembelajaran bahasa Indonesia merupakan salah satu mata pelajaran yang wajib dipelajari oleh siswa di sekolah dasar karena bahasa Indonesia merupakan sarana yang digunakan sehari-hari. Pembelajaran bahasa Indonesia di sekolah dasar diarahkan untuk meningkatkan kemampuan siswa dalam berkomunikasi menggunakan bahasa Indonesia yang baik dan benar, baik secara lisan maupun tulis, serta menumbuhkan apresiasi terhadap hasil karya kesastraan manusia Indonesia (BSNP, 2006 dalam Sufanti, 2010). Aspek keterampilan yang harus dipelajari dalam pembelajaran bahasa Indonesia antara lain keterampilan menyimak, keterampilan membaca, keterampilan menulis, keterampilan berbicara dan semua saling berhubungan satu sama lain serta harus diajarkan secara bertahap guna meningkatkan mutu pembelajaran bahasa Indonesia di sekolah dasar.

Salah satu keterampilan berbahasa yang dipelajari pada pembelajaran bahasa Indonesia di sekolah dasar adalah keterampilan menulis. Menulis adalah suatu keterampilan bahasa yang bersifat produktif serta sangat dibutuhkan dalam kehidupan sehari-hari. Keterampilan menulis tidak datang begitu saja tetapi harus melalui tahapan latihan dan proses yang berkesinambungan agar mencapai hasil yang maksimal, sesuai pendapat Tarigan (2008) yang menyatakan bahwa keterampilan hanya dapat diperoleh dan dikuasai dengan jalan praktik dan banyak latihan.

Pembelajaran menulis di sekolah dasar dibedakan menjadi pembelajaran menulis permulaan dan menulis tingkat lanjut. Pada pembelajaran menulis tingkat permulaan siswa belajar teknik menulis sedangkan pada tingkat lanjut siswa belajar mengungkapkan idea tau gagasan dalam bentuk tulisan sederhana dengan ejaan yang benar, contohnya adalah menulis karangan sederhana dalam bentuk puisi.

Kenyataannya masih banyak siswa yang kesulitan menuangkan ide/gagasannya dalam tulisan terutama puisi dan membuktikan bahwa pembelajaran keterampilan menulis puisi di sekolah dasar masih kurang. Permasalahan ini ditemukan di SD Negeri 2 Jetis Kecamatan Kemangkon Kabupaten Purbalingga yang dibuktikan dengan hasil pratindakan mata pelajaran Bahasa Indonesia kompetensi menulis puisi kelas IV yang terdiri dari 15 siswa hanya 3 siswa (20\%) yang masuk kategori Terampil sedangkan 12 siswa lainnya (80\%) masih dalam kategori Tidak Terampil.

Keberhasilan dalam keterampilan menulis pada siswa dipengaruhi oleh berbagai faktor. Sesuai dengan hasil observasi dan wawancara yang dilakukan oleh peneliti maka diperoleh data bahwa rendahnya keterampilan menulis puisi siswa dikarenakan oleh beberapa faktor antara lain masih sulitnya siswa menuangkan ide-ide menjadi sebuah tulisan sehingga masih sering dibantu guru dan guru masih belum menggunakan model pembelajaran yang bervariatif dalam kegiatan pembelajaran.

Dilihat dari permasalahan diatas maka dibutuhkan suatu cara agar mendorong siswa terampil menulis puisi, salah satu cara yang dapat digunakan adalah dengan menggunakan penerapan model pembelajaran yang inovatif. Terdapat berbagai model pembelajaran yang ada saat ini, salah satu yang dapat dijadikan alternatif adalah model pembelajaran Think Talk Write (TTW). Model tersebut mendorong siswa untuk berfikir, berbicara atau dalam hal ini mengemukakan pendapat kemudian kembali berfikir sebelum menuangkan gagasannya dalam bentuk tulisan. Sesuai dengan pendapat Huda (2013) yang menyatakan bahwa model pembelajaran Think Talk Write (TTW) digunakan untuk mengembangkan tulisan dengan lancar dan melatih bahasa sebelum dituliskan. Proses pengembangan yang dimaksud akan dilakukan dalam proses pembelajaran dengan menerapkan model Think Talk Write (TTW) yang mengandung tiga unsur yaitu, (1) Think yaitu siswa membaca atau mengidentifikasi gagasan yang terkandung dalam suatu media, (2) Talk yaitu siswa berdiskusi dengan teman sekelompoknya, (3) Write yaitu siswa menuliskan gagasan yang diperolehnya dari tahapan Think dan Talk. Model pembelajaran Think Talk Write (TTW) merupakan model pembelajaran yang mendukung siswa menulis secara berkelompok, seperti 
pernyataan Suminar dan Putri (2015) yang menyatakan bahwa model pembelajaran kooperatif tipe Think Talk Write (TTW) dapat menjadi fasilitas bagi siswa dalam menulis karena siswa mempraktikkan langsung bersama-sama dalam kelompok.

Keterampilan menulis puisi perlu ditingkatkan karena berawal dari menulis karangan sederhana seperti puisi maka siswa akan terbiasa dengan menyampaikan gagasannya dalam bentuk tulisan sederhana dan relatif singkat sehingga siswa akan lebih terpacu dalam menulis jenis karangan lainnya atau bentuk tulisan yang lebih kompleks sesuai jenjang pendidikannya kelak.

Adapun tujuan penelitian ini adalah untuk meningkatkan keterampilan menulis puisi pada siswa kelas IV SD N 2 Jetis Kabupaten Purbalingga Tahun Ajaran 2017/2018.

Berdasarkan latar belakang diatas maka dapat dirumuskan "Apakah penerapan model pembelajaran Think Talk Write (TTW) dapat meningkatkan keterampilan menulis puisi pada siswa kelas IV SD N Jetis Kabupaten Purbalingga Tahun Ajaran 2017/2018?

\section{METODE}

Penelitian ini menggunakan pendekatan Penelitian Tindakan Kelas (PTK) atau Classroom Action Research. Masuk dalam kategori PTK karena lebih menekankan pada proses perbaikan dalam suatu pembelajaran di kelas dengan menerapkan tindakan berupa penggunaan model Think Talk Write (TTW) untuk mengatasi rendahnya keterampilan menulis puisi dalam pembelajaran Bahasa Indonesia. Hal ini sesuai dengan pendapat Daryanto (2014) yang menyatakan bahwa Penelitian Tindakan Kelas (PTK) adalah penelitian yang dilakukan oleh guru di dalam kelasnya sendiri melalui refleksi diri dengan tujuan untuk memperbaiki kualitas proses pembelajaran di kelas, sehingga hasil belajar siswa dapat ditingkatkan.

Data yang dikumpulkan peneliti adalah berupa data kualitatif dan data kuantitatif. Data kualitatif berupa hasil wawancara, hasil observasi kinerja guru, dan aktifitas siswa selama pembelajaran menggunakan model Think Talk Write (TTW). Data kuantitatif berupa nilai keterampilan menulis puisi dan nilai hasil evaluasi setiap pertemuan. Sumber data dibagi menjadi dua yaitu sumber data primer dan sumber data sekunder. Sumber data primer dalam penelitian ini adalah siswa kelas IV yang berjumlah 15 orang dan seorang guru kelas, serta informasi mengenai keadaan siswa dan kegiatan guru saat mengajar. Sedangkan sumber data sekunder antara lain arsip berupa perangkat pembelajaran, lembar observasi, foto, dan video dalam pelaksanaan pembelajaran menggunakan model Think Talk Write (TTW) serta dokumentasi berupa hasil penilaian pada pra siklus, siklus I dan siklus II.

Teknik pengumpulan data dalam penelitian ini dilakukan dengan observasi, wawancara, tes, dan dokumentasi. Sedangkan teknik analisis data yang digunakan adalah teknik analisis interaktif dari Miles dan Huberman.

\section{HASIL DAN PEMBAHASAN}

Hasil yang didapat dari penelitian ini adalah sejumlah data dari observasi awal sebelum dilakukan tindakan hingga hasil nilai per siklus. Adapun kondisi awal keterampilan menulis puisi yang diketahui dari hasil uji pra tindakan dan didapatkan data bahwa hanya 3 siswa (20\%) yang memperoleh nilai diatas Kriteria Ketuntasan Minimal (KKM) yang ditentukan yaitu 75 atau yang masuk dalam kategori Terampil dan 12 siswa lainnya (80\%) masih dalam kategori Tidak Terampil, rata-rata nilai yang siswa dapatkan pun masih dalam kategori rendah yaitu 47. Hal tersebut dapat diamati pada tabel 1 dan gambar 1 dibawah ini. 
Tabel 1. Distribusi Frekuensi Nilai Keterampilan Menulis Puisi Pratindakan

\begin{tabular}{|c|c|c|c|c|c|}
\hline No & Interval & $\begin{array}{l}\text { Frekuensi } \\
\text { (fi) }\end{array}$ & $\begin{array}{c}\text { Nilai Tengah } \\
\text { (xi) }\end{array}$ & fi.xi & $\begin{array}{c}\text { Persentase } \\
\text { (\%) }\end{array}$ \\
\hline 1 & $25-35$ & 5 & 30 & 150 & 33,33 \\
\hline 2 & $36-46$ & 4 & 41 & 164 & 26,67 \\
\hline 3 & $47-57$ & 2 & 52 & 104 & 13,33 \\
\hline 4 & $58-68$ & 1 & 63 & 63 & 6,67 \\
\hline 5 & $69-79$ & 3 & 74 & 222 & 20,00 \\
\hline Juml & & 26 & & 703 & 100 \\
\hline \multicolumn{3}{|c|}{ Rata-rata nilai } & & $(703: 15)$ & $=47$ \\
\hline \multicolumn{3}{|c|}{ Ketuntasan klasikal } & & \multicolumn{2}{|c|}{$(3: 15) \times 100 \%=20 \%$} \\
\hline \multicolumn{3}{|c|}{ Nilai tertinggi } & & \multicolumn{2}{|l|}{75} \\
\hline \multicolumn{3}{|c|}{ Nilai terendah } & & \multicolumn{2}{|l|}{25} \\
\hline
\end{tabular}

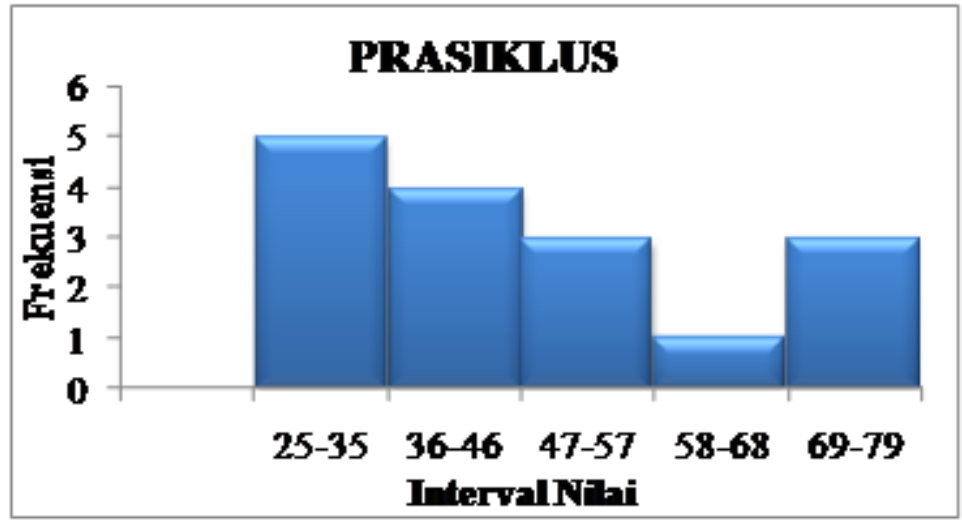

Gambar 1. Grafik Nilai Keterampilan Menulis Puisi Pratindakan

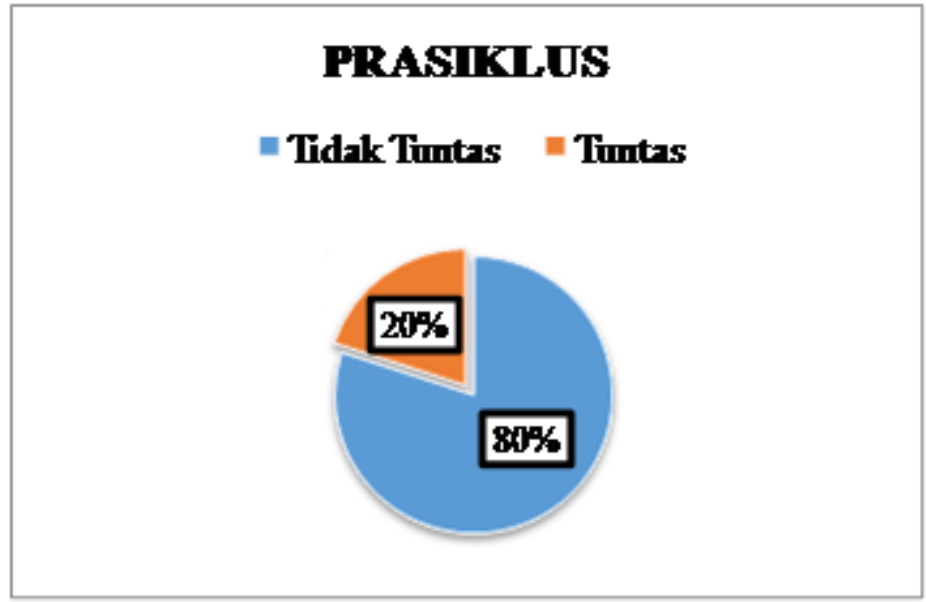

\section{Gambar 2. Grafik Ketuntasan Keterampilan Menulis Puisi Pratindakan}

Pada siklus I pembelajaran sudah menerapkan model pembelajaran Think Talk Write (TTW), peneliti juga mengamati kinerja guru dan aktifitas siswa. Pada siklus ini terjadi peningkatan yaitu terdapat 9 siswa (60\%) yang masuk kategori Terampil dan masih ada 6 siswa (40\%) yang masih dikategorikan Tidak Terampil, rata-rata kelas pun naik menjadi 71,83 . 
Pedoman penilaian kinerja guru terdiri dari indikator yang berkaitan dengan penerapan model Think Talk Write (TTW) dalam proses pembelajaran berupa pra pembelajaran, membuka pelajaran, inti pelajaran, dan menutup pelajaran. Hasil yang didapatkan berupa rata- rata nilai yaitu 3,00 yang artinya kinerja guru dalam mengajar sudah dalam kondisi baik namun masih terdapat kekurangan sehingga masih perlu adanya peningkatan kinerja guru dalam mengajar. Hasil tersebut dapat dilihat pada tabel berikut.

Tabel 2. Skor Penilaian Pengamatan Kinerja Guru Siklus I

\begin{tabular}{ccc}
\hline No & Pertemuan & Penilaian Kinerja Guru \\
\hline 1 & Pertemuan I & 2,87 \\
2 & Pertemuan II & 3,13 \\
\hline & Jumlah & 6,00 \\
\hline & Rata-rata & 3,00 \\
\hline
\end{tabular}

Aktifitas siswa pun diamati dalam beberapa aspek antara lain aktifitas melihat, aktifitas berbicara, aktifitas mendengarkan, aktifitas menulis, aktifitas mental, dan aktifitas emosional. Hasil penilaian aktifitas siswa dapat dilihat pada tabel dan grafik berikut.

Tabel 3. Skor Penilaian Aktifitas Siswa Siklus I

\begin{tabular}{lccc}
\hline Aspek Aktifitas & $\begin{array}{c}\text { Rata-rata } \\
\text { Skor } \\
\text { Pertemuan 1 }\end{array}$ & $\begin{array}{c}\text { Rata-rata } \\
\text { Skor } \\
\text { Pertemuan 2 }\end{array}$ & $\begin{array}{c}\text { Rata-rata } \\
\text { skor siklus } \\
\mathbf{1}\end{array}$ \\
\hline Melihat & 2 & 3 & 2,5 \\
\hline Berbicara & 2,33 & 3 & 2,67 \\
\hline Mendengarkan & 2,33 & 3,33 & 2,33 \\
\hline Menulis & 3,67 & 4 & 3,83 \\
\hline Mental & 2,33 & 3 & 2,67 \\
\hline Emosional & 3,33 & 3,67 & 3,5 \\
\hline Jumlah & 15,99 & 20 & 17,99 \\
\hline
\end{tabular}

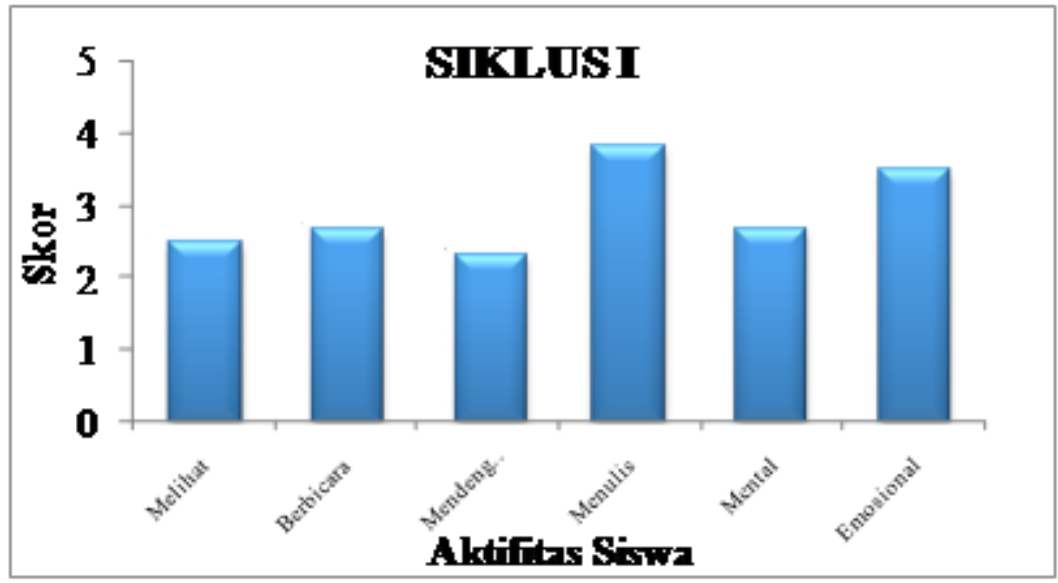

Gambar 3. Grafik Observasi Aktifitas Siswa Siklus I 
Hasil penilaian keterampilan menulis puisi pada siklus I disajikan dalam tabel dan grafik berikut.

Tabel 4. Distribusi Frekuensi Nilai Keterampilan Menulis Puisi Siklus I

\begin{tabular}{|c|c|c|c|c|c|}
\hline No & Interval & $\begin{array}{l}\text { Frekuensi } \\
\text { (fi) }\end{array}$ & $\begin{array}{l}\text { Nilai Tengah } \\
\text { (xi) }\end{array}$ & fi.xi & $\begin{array}{c}\text { Persentase } \\
(\%)\end{array}$ \\
\hline 1 & $50-57$ & 2 & 53,5 & 107 & 13,33 \\
\hline 2 & $58-65$ & 2 & 61,5 & 123 & 13,33 \\
\hline 3 & $66-73$ & 2 & 69,5 & 139 & 13,33 \\
\hline 4 & $74-81$ & 7 & 77,5 & 542 & 46,67 \\
\hline 5 & $82-89$ & 2 & 85,5 & 171 & 13,33 \\
\hline \multicolumn{2}{|c|}{ Jumlah } & 15 & & 1082,5 & 100 \\
\hline \multicolumn{3}{|c|}{ Rata-rata nilai } & & $(1082,5: 15)$ & $=72,17$ \\
\hline \multicolumn{3}{|c|}{ Ketuntasan klasikal } & & \multicolumn{2}{|c|}{$(9: 15) \times 100 \%=80 \%$} \\
\hline \multicolumn{3}{|c|}{ Nilai tertinggi } & & \multicolumn{2}{|l|}{85} \\
\hline \multicolumn{3}{|c|}{ Nilai terendah } & & \multicolumn{2}{|l|}{50} \\
\hline
\end{tabular}

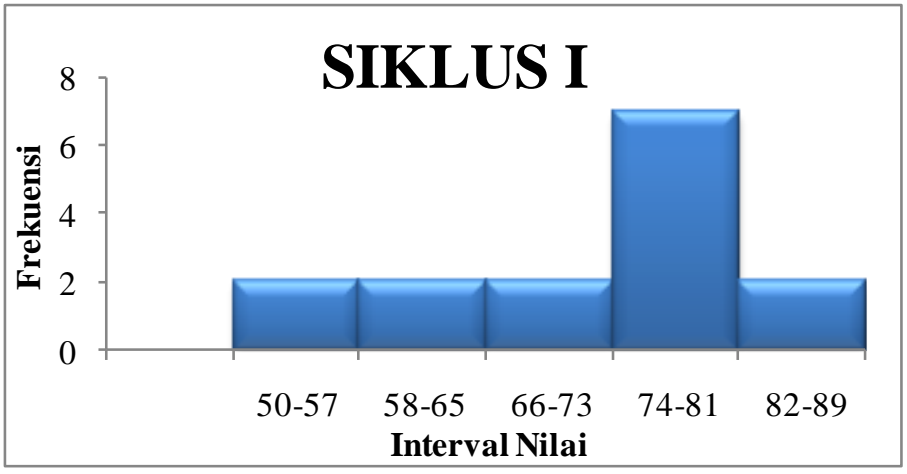

\section{Gambar 4. Grafik Nilai Keterampilan Menulis Puisi Siklus I}

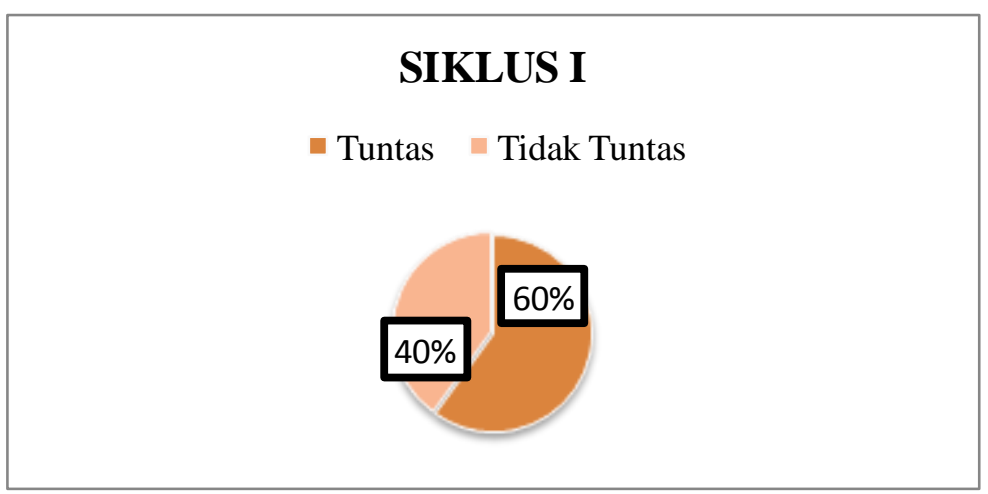

\section{Gambar 5. Grafik Ketuntasan Keterampilan Menulis Puisi Siklus I}

Setelah siklus I selesai dilaksanakan refleksi dan berdasarkan hasil yang diperoleh maka diputuskan masih perlu dilakukan perbaikan di siklus II. Pada siklus II kegiatan yang dilakuka hampir sama dengan siklus I bedanya jika di siklus I media yang digunakan dalam pembelajaran adalah gambar sedangkan pada siklus II menggunakan media video. Hasil yang didapatkan pada siklus II yaitu terjadi peningkatan rata-rata nilai keterampilan menulis puisi yaitu 77,67 dan 13 siswa masuk 
dalam kategori Terampil (86,67\%) 2 siswa lainnya masih termasuk kategori Tidak Terampil. Data tersebut disajikan dalam tabel dan gambar berikut.

Tabel 5. Distribusi Frekuensi Nilai Keterampilan Menulis Puisi Siklus II

\begin{tabular}{|c|c|c|c|c|c|}
\hline No & Interval & $\begin{array}{l}\text { Frekuensi } \\
\text { (fi) }\end{array}$ & $\begin{array}{c}\text { Nilai Tengah } \\
\text { (xi) }\end{array}$ & fi.xi & $\begin{array}{c}\text { Persentase } \\
(\%)\end{array}$ \\
\hline 1 & $55-62$ & 2 & 85,5 & 117 & 113,33 \\
\hline 2 & $63-70$ & 0 & 66,5 & 0 & 0,00 \\
\hline 3 & $71-78$ & 5 & 74,5 & 372,5 & 33,33 \\
\hline 4 & $79-86$ & 6 & 82,5 & 495 & 40,00 \\
\hline \multirow[t]{2}{*}{5} & $87-94$ & 2 & 90,5 & 181 & 13,33 \\
\hline & & 15 & & 1165,5 & 100 \\
\hline \multicolumn{4}{|c|}{ Rata-rata nilai } & \multicolumn{2}{|c|}{$(1165: 15)=77,67$} \\
\hline \multicolumn{4}{|c|}{ Ketuntasan klasikal } & \multicolumn{2}{|c|}{$(13: 15) \times 100 \%=86,67 \%$} \\
\hline \multicolumn{4}{|c|}{ Nilai tertinggi } & \multicolumn{2}{|l|}{90} \\
\hline \multicolumn{4}{|c|}{ Nilai terendah } & \multicolumn{2}{|l|}{55} \\
\hline
\end{tabular}

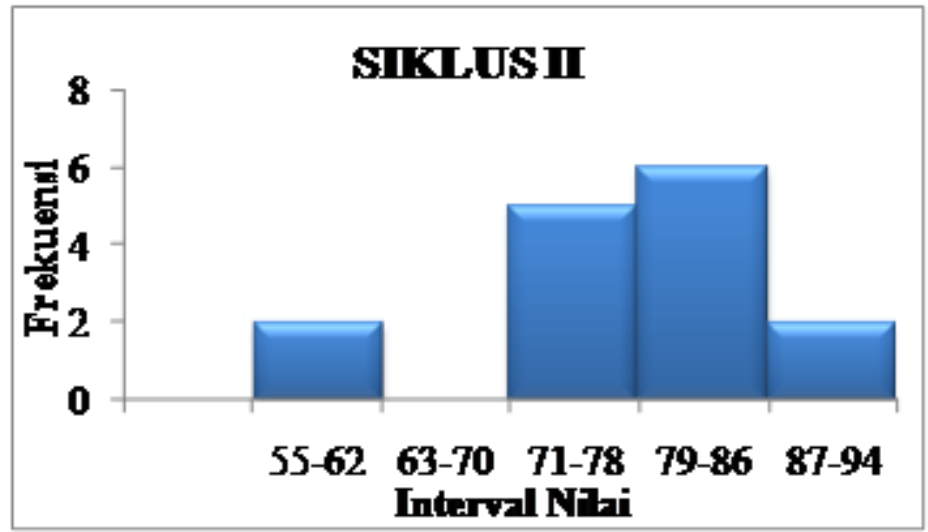

Gambar 6. Grafik Nilai Keterampilan Menulis Puisi Siklus II

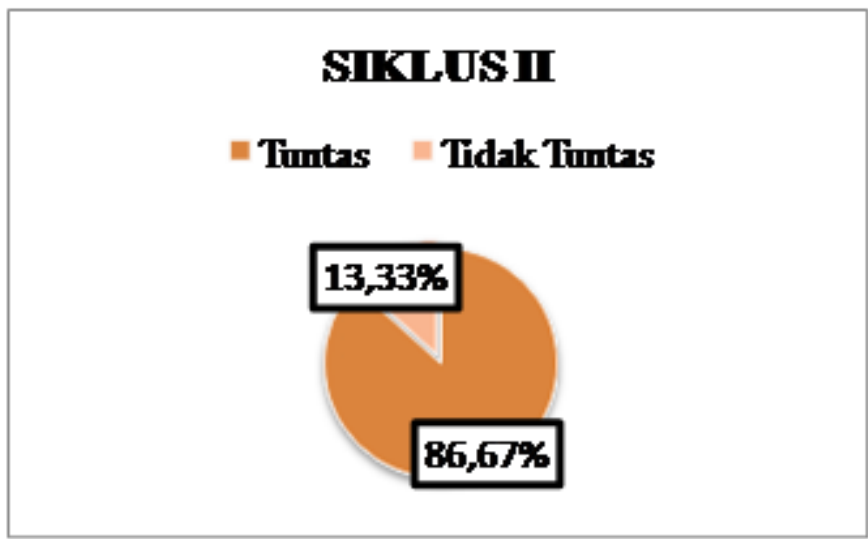

\section{Gambar 7. Grafik Ketuntasan Keterampilan Menulis Puisi Siklus II}

Adapun penilaian kinerja guru dan aktifitas siswa pun mengalami peningkatan, kinerja guru meningkat menjadi 3,57 yang berarti guru dalam mengajar sudah dalam kondisi sangat bagus. Data tersebut disajikan dalam tabel dan grafik berikut ini. 
Tabel 6. Skor Penilaian Pengamatan Kinerja Guru Siklus II

\begin{tabular}{ccc}
\hline No & Pertemuan & Penilaian Kinerja Guru \\
\hline 1 & Pertemuan I & 3,40 \\
2 & Pertemuan II & 3,73 \\
\hline & Jumlah & 7,13 \\
\hline Rata-rata & 3,57
\end{tabular}

Tabel 7. Skor Penilaian Aktifitas Siswa Siklus II

\begin{tabular}{lccc}
\hline Aspek Aktifitas & $\begin{array}{c}\text { Rata-rata } \\
\text { Skor } \\
\text { Pertemuan 1 }\end{array}$ & $\begin{array}{c}\text { Rata-rata } \\
\text { Skor } \\
\text { Pertemuan 2 }\end{array}$ & $\begin{array}{c}\text { Rata-rata } \\
\text { skor siklus } \\
\text { II }\end{array}$ \\
\hline Melihat & 3,33 & 3,67 & 3,35 \\
\hline Berbicara & 3,67 & 3,67 & 3,67 \\
\hline Mendengarkan & 3.67 & 4 & 3.83 \\
\hline Menulis & 4 & 4 & 4 \\
\hline Mental & 3.67 & 3.67 & 3.33 \\
\hline Emosional & 3.67 & 4 & 3.83 \\
\hline Jumlah & 15,01 & 15,67 & 14,99 \\
\hline
\end{tabular}

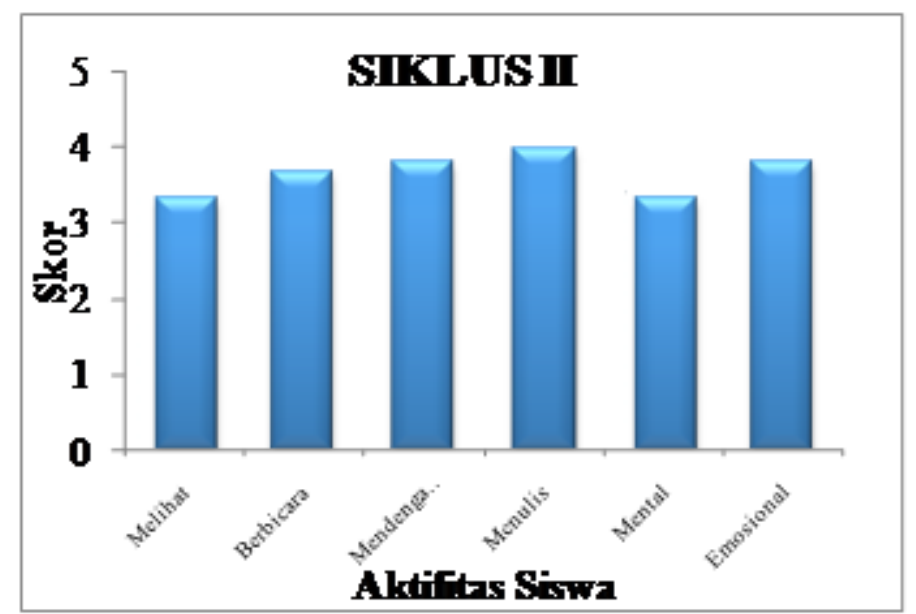

Gambar 8. Grafik Observasi Aktifitas Siswa Siklus II

\section{SIMPULAN}

Berdasarkan paparan hasil penelitian diatas maka dapat diambil simpulan bahwa model pembelajaran Think Talk Write (TTW) dapat meningkatkan keterampilan menulis puisi pada siswa kelas IV SD N 2 Jetis Kabupaten Purbalingga Tahun Ajaran 2017/2018. Hal ini dibuktikan dengan adanya peningkatan nilai keterampilan di tiap siklus.

Pada pratindakan terdapat 3 siswa (20\%) masuk kategori Terampil sedangkan 12 siswa (80\%) tergolong kategori Tidak Terampil dengan nilai rata-rata kelas 47. Setelah diterapkan model pembelajaran Think Talk Write (TTW) jumlah siswa yang tergolong Terampil menjadi 9 siswa $(60 \%)$ sedangkan 6 siswa $(40 \%)$ masih tergolong 
Tidak Terampil dan nilai rata-rata kelas meningkat menjadi 71,83 . Karena pencapaian KKM belum sesuai dengan indikator kinerja penelitian maka perbaikan dilanjutkan pada siklus II. Pelaksanaan siklus II memberikan hasil yaitu sebanyak 13 siswa $(86,67 \%)$ tergolong Terampil dengan nilai rata-rata kelas sebesar 77,67 . Karena pembelajaran telah mencapai indikator kinerja penelitian $80 \%$ maka siklus dihentikan pada siklus II.

Peningkatan terjadi pada penelitian ini karena model pembelajaran Think Talk Write (TTW) merupakan model yang tidak terlalu sulit untuk digunakan dan model ini memberikan kesempatan siswa untuk berpikir lebih luas serta dapat menumbuhkan kerjasama antar siswa. Hal tersebut sesuai dengan pendapat Shoimin (2016) yang menyebutkan bahwa kelebihan menerapkan model pembelajaran tipe Think Talk Write (TTW) yaitu:

1) Mengembangkan pemecahan yang bermakna dalam materi ajar

2) Peserta didik dapat mengembangkan keterampilan berfikir kritis dan kreatif dengan memberikan soal open minded

3) Peserta didik akan aktif dalam belajar karena adanya interaksi dalam kegiatan kelompok

4) Membiasakan peserta didik berfikir dan berkomunikasi dengan teman, guru, bahkan dengan diri mereka sendiri.

Penelitian ini dapat dijadikan masukan untuk guru memberikan inovasi dalam pembelajaran baik. Semoga penelitian ini dapat bermanfaat bagi siswa, guru, sekolah, maupun peneliti lain.

\section{DAFTAR PUSTAKA}

Daryanto. (2014). Penelitian Tindakan Kelas dan Penelitian Tindakan Sekolah Beserta Contoh-contohnya. Yogyakarta: Gava Media

Huda, M. (2013). Model dan Metode Pembelajaran: Isu-isu Metodis dan Paradismatis. Yogyakarta: Pustaka Pelajar

Shoimin, A. (2016). 68 Model Pembelajaran Inovatif dalam Kurikulum 2013. Yogyakarta: Ar-Ruzz Media

Sufanti, Main. (2010). Strategi Pengajaran Bahasa dan Sastra Indonesia. Surakarta: Yuma Pustaka

Suminar,R.P \& Putri, G. (2015) The Effectiveness of TTW ( Think-Talk-Write) Strategy in Teaching Writing Descriptive Text. Journal of English Language and Learning, 2(2), 299-304

Tarigan, H.G. (2008). Menulis Sebagai Suatu Keterampilan Berbahasa. Bandung: Angkasa 